\title{
Elements in Multimedia Interactive Package (MIP) Production to Facilitate Critical Thinking Acquisition in ESL Reading
}

Noraini Ahmad Basri, Othman Ismail, Malissa Maria Mahmud

To Link this Article: http://dx.doi.org/10.6007/IJARBSS/v11-i1/8470

DOI:10.6007/IJARBSS/v11-i1/8470

Received: 01 November 2020, Revised: 30 November 2020, Accepted: 24 December 2020

Published Online: 27 January 2021

In-Text Citation: (Basri et al., 2021)

To Cite this Article: Basri, N. A., Ismail, O., \& Mahmud, M. M. (2021). Elements in Multimedia Interactive Package (MIP) Production to Facilitate Critical Thinking Acquisition in ESL Reading. International Journal of Academic Research in Business and Social Sciences, 11(1), 633-644.

Copyright: (c) 2021 The Author(s)

Published by Human Resource Management Academic Research Society (www.hrmars.com)

This article is published under the Creative Commons Attribution (CC BY 4.0) license. Anyone may reproduce, distribute, translate and create derivative works of this article (for both commercial and non-commercial purposes), subject to full attribution to the original publication and authors. The full terms of this license may be seen at: http://creativecommons.org/licences/by/4.0/legalcode

Vol. 11, No. 1, 2021, Pg. 633 - 644

Full Terms \& Conditions of access and use can be found at http://hrmars.com/index.php/pages/detail/publication-ethics 


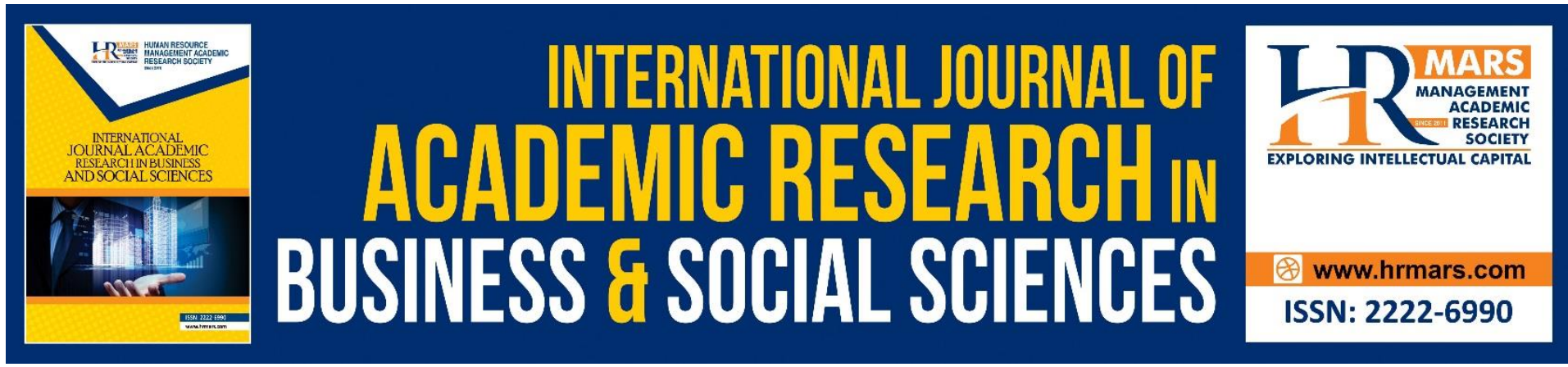

\title{
Elements in Multimedia Interactive Package (MIP) Production to Facilitate Critical Thinking Acquisition in ESL Reading
}

\author{
Noraini Ahmad Basri, Othman Ismail \\ Akademi Pengajian Bahasa (APB), Universiti Teknologi MARA, 40450 Shah Alam, Selangor, \\ Malaysia \\ Email:noraini013@uitm.edu.my, othmani@uitm.edu.my
}

\author{
Malissa Maria Mahmud \\ Centre for English Language Studies (CELS), Sunway University, No. 5, Jalan, Universiti, \\ Bandar Sunway, 47500, Petaling Jaya, Selangor, Malaysia \\ Email: malissam@sunway.edu.my
}

\begin{abstract}
This paper examines content elements that effectively facilitate L2 learners' critical thinking skills in ESL reading when using a Multimedia Interactive Package (MIP). The MIP was designed to incorporate the 'demand task' components of Weir's validation reading framework. Ninety-two treatment group respondents were requested to respond to a set of questionnaire on content elements needed to be included into the MIP. Overall, majority of the respondents, either 'agreed' or 'strongly agreed', positively perceived that 'demand task' components - discourse mode, channel of communication, text length, nature of information, content knowledge, lexical, structural and functional - facilitated them at acquiring higher order thinking skills more effectively. Coupled with the use of computer-mediated interactive multimedia capabilities which could provide drills and exercises, immediate reinforcement and feedback, online tests and dynamic learning engagement, MIP intervention can facilitate learning success amongst L2 learners' critical thinking skills in ESL reading.

Keywords: Blended Learning, Higher Order Thinking Skills (HOTs), Demand Task, Content Elements, Multimedia Interactive Package (MIP)
\end{abstract}

\section{Introduction}

Improving higher order thinking skills amongst L2 learners' ESL reading has been remarkably challenging. Bloom's Taxonomy of Higher Order Thinking skills (HOTs) stresses on the development of learners' analysis, synthesis and evaluation skills. Its underpinning and groundwork concepts ensue its feasibility and application even for technological integration (Mahmud et al., 2019). In this context, the radical transformation of pedagogic practices necessitates embedded novelty of thinking skills in order to cultivate excellent prospects for exploration, experimentation, training, and enhancement, and in due course, allowing for 
continuous improvement of individual capabilities (Abdul, 2016). Some ingenuities to harness high-order thinking is to employ teachers' teaching methods to produce quality students with quality thinking skills (Ibrahim et al., 2019). Some might argue that this is rather a no brainer. Albeit the perceived commonalities, changes made for pedagogical practices also involve teachers' efforts to formulate thoughtful activities that can augment students' cognitive abilities such as planned exercises that induce and conjure pertinent issue in question. Therefore, students are able to be engaged in numerous ways by looking at a case from various perspectives.

When learners are confronted with critical reading materials, they are required to apply these HOTs in order to make meaningful inferences and interpretation of the reading materials. Therefore, the need for learners to master their reading comprehension at the university level is vital in determining how they wheel their way into the employment industry upon graduation. Using authentic materials in English classes, for example, is one of the strategies that educators employ to enhance their teaching; and, this can also help to increase learners' understanding of the English language (Tomlinson, 2011). Correspondingly, the national curriculum also emphasizes that the teaching and learning activities should incorporate the use of local materials to reflect true and authentic Malaysian environments so that learners could relate to and react critically and meaningfully to any reading material presented. Local flavored materials should be included in the reading activities as these materials can better gauge learners' understanding. It is also difficult to learn and acquire any language without adequate practice and assistance of the language. Providing drills and practices with immediate feedback and reinforcements are techniques that can improve learners' understanding of the learning (Gagne, 1992, as cited in Jarvis, 2004). Therefore, providing instructional experiences and opportunities that can assist learners to become successful in their learning is crucial. A computer-based reading tool, equipped with interactive and multimedia elements, could facilitate the development of L2 learners' language acquisition (Auphan et al., 2019; Pinandito et al., 2020; Shao, 2012).

\section{Problem Statement}

Developing learners' critical thinking skills in reading at tertiary level is crucial because learners lack language proficiency and competency especially in analyzing, synthesizing and evaluating academic reading materials. At Universiti Teknologi MARA (UiTM), Malaysia, for instance, learners in the Business School are required to apply Higher Order Thinking skills (HOTs) when solving business case studies. Law learners need to be able to study, interpret, and argue based on previous legal cases. Students pursuing English for Professional Communication require critical thinking skills in negotiation and persuasion activities. In addition, learners from various faculties require the knowledge and skills of Advanced Reading in ESL classes that train them to develop higher order thinking skills. However, there is evidently a gap between what is expected of the learners' language competency skills and their achievements in reading and critical thinking. Their grades for the course, Reading and Critical, are low. Hence, teaching critical reading skills and evaluating learners' knowledge and skills in applying HOTs in ESL reading and critical thinking are relevant challenges to be addressed.

Lack of effective language learning strategies in a non-native language environment also inhibits language learning and acculturation. At the Academy of Language Studies (ALS), 
UiTM, Malaysia, a Reading and Critical Thinking course is offered where learners are exposed to higher order thinking skills. Despite various conventional learning strategies used in the classroom, L2 learners still face difficulties at acquiring critical thinking skills in their reading activities. Among the challenges expressed by the learners include the lack of immediate support from the faculty members, limited contact hours, large number of learners per class and the inadequate use of authentic reading materials relevant to the learners' cultural background. Solving these shortcomings is vital to ensure that the teaching of critical reading skills can be made effective and successful. Perhaps, an integration of computer-based teaching tools with appropriate selection of content elements be adapted as an alternative strategy to assist in the learning process. Thus, the primary aim of the study is to examine the content elements needed in the design and development of a customized Multimedia Interactive Package (MIP) that facilitates critical thinking skills in ESL reading.

\section{Literature Review}

Weir (2005) introduces a reading validation framework that examines and validates reading tests. In his framework, he discusses about context validity, theory-based validity and scoring validity. For this paper, however, only Weir's context validity - specifically task demand, will be discussed since the paper focuses only on the development of the reading contents used with the support of computer-mediated learning tool. Weir emphasizes that the task demand components should be carefully considered when selecting reading materials. The components are the discourse mode, channel of communication, text length, writer-reader relationship, nature of information, content knowledge, lexical, structural and functional. In the discourse mode, Weir stresses that instructional developers designing reading tests and materials need to carefully decide on the types of tests appropriate for the test takers. Close attention should be given to include authentic texts that have similar proximity to the targetlanguage scenarios. Common target-language features can facilitate learners to better understand the reading contents. Furthermore, the length of the texts is also crucial when testing different reading skills. Short texts can be used to test careful reading rather than expeditious reading and vice versa. Text length also has different effects on cognitive processing. Weir divided reading as global and local comprehension (Khalifa, 2010). Global means readers relate ideas in a paragraph which are logical and rhetorical while local means readers relate individual sentences that are mechanical or syntactical. Examples of reading at a global stage are skimming for the gist of the text or locating information on a predetermined topic. Examples of reading at a local stage are scanning to locate specific information and reading carefully to infer the meaning of the text.

A careful reading focuses on the ability of readers to engage in and to comprehend every part of the contents of a text (Weir, 2005). A careful reading at the global stage establishes accurate comprehension of the stated main idea the author would like to convey. However, careful reading at the local level exemplifies the understanding of the syntactic structure of sentences and clauses as well as inferring the meaning of lexical item (Weir, Yang, Yan, 2000). It also involves the skill of deducing meaning of lexical items of a paragraph or passage (Zagliverinos, 2008). Weir (2005) referred to expeditious reading as a process that involves readers to read quickly, selectively and effectively on any given reading text. The expeditious reading at the global level emphasizes on the skimming skill that establishes the topic and main idea of a particular passage - that is, what the whole passage is about. This involves the skills of locating and searching quickly for the information and understanding the information 
given. Here, readers build a macrostructure with minimal information from the passage that they read (Krishnan, 2013). Meanwhile, the expeditious reading at the local level highlights the scanning skill used to locate specific information such as names, dates, data figures or words (Zagliverinos, 2008). This process is selective because readers have to locate for specific information and disregard parts that are not important.

The nature of information selected in reading materials may contain both abstract and concrete information. Depending on the cognitive and linguistic capabilities of the learners, the selected reading materials and tests that comprise both abstract and concrete information may cause difficulties for learners to digest or comprehend. Therefore, developers need to carefully consider the nature of information found in the reading materials to match that of the learners' prior knowledge, contents and language exposure. Here, the relationship between the test takers' or learners' background knowledge and the content knowledge is important. This is crucial because (Urquhart \& Weir, 1998) test takers can deploy their existing schemata to make connections with the new reading contents, and to deploy their existing knowledge, skills and strategies to further understand the new contents. Subsequently, developers should consider the familiarity of lexical used, the syntax or structural used and the specific function of the reading materials. Reading materials which are full of content-based vocabulary may not be appropriate for learners at their elementary learning levels. Similarly, the use of sentence structures - for example, simple, compound, complex and compound-complex sentences, in reading contents and tests can also have different impact on learners' understanding and comprehension. Reading texts with simple grammar tend to be easier than texts with complex grammar. In addition, reading texts are written to serve a variety of language functions. Some English for Specific Purpose (ESP) reading materials are not written for general readers. Most of these ESP materials are written with full of language jargons and terminologies closely related to the specific subject matter. Thus, a Science-based reading material may not be suitable for learners from the field of Humanities. Reading materials prepared for learners taking tests of English for Specific Purposes should, therefore, be designed and developed using appropriate types of lexical and syntax.

Our current education is constantly being shaped technologically, transcending the traditional method to a more modern approach in teaching and learning. There is no doubt that technology has contributed tremendously in facilitating a better way of acquiring knowledge, information and skills. At present, as technology advances, more interactive computer-aided learning (CAL) facilities are seen in our classrooms with the integration of various telecommunication media (Park \& Son, 2009; Berk, 2009). Mahmud in her meta-analysis study suggested that the employment of technology augment learners' performance and is therefore efficacious to teaching and learning (2018). In the effort to enhance knowledge and skills in reading through technology, educators, instructional developers and designers have explored various computer-aided tools capable of creating learning environments that can gauge learners' interest and stimulate their learning. In reading activities, for example, many research studies have documented learners' learning achievements in different reading skills when they worked using computer-assisted applications (Pearman, 2008; Despirt, 2009; Moody, 2010; Alemi \& Lari, 2012; Bataineh, 2014; Khodaparast, \& Ghafournia, 2015). Learners had shown improvements in their reading skills such as in their vocabulary growth, comprehension, analysis and synthesis skills. 
In reading comprehension, research studies have also shown similar trend in learners' improvements. In one investigation done by Moody (2010), found that the use of estorybooks has supported not only the vocabulary development of learners, but also created active engagement and improved comprehension of story. Another study using CD-based storybooks, with interactive multimedia capabilities, has also been reported to aid learners' comprehension. Such interactive multimedia application is capable of providing reading experiences for learners to acquire and understand information that cannot be replicated by static, traditional texts (Pearman, 2008). Yousif Alshumaimeri and Meshail Almasri (2012) conducted a study that examined the effects of using WebQuest on Saudi male EFL learners reading comprehension performance. In this study, the learners were exposed to several online resources and they were required to gather information about a specific topic. Using the WebQuest, learners were exposed to many types of online materials and sources where they had to apply their reading skills such as evaluating the validity of texts, selecting appropriate sources and synthesizing materials to form meaning. The experimental group received traditional teaching plus WebQuest as supplementary activities; while, the control group received only the traditional teaching method. The results of the study indicated that there were significant differences between the experimental group post-test comprehension performance $(t=8.567, p=0.000)$ when compared to the control group pre-test comprehension performance. The findings concluded that WebQuest tool has the ability to promote learners reading comprehension. A study conducted in India among striving readers, where GraphoLearn, a computer-assisted reading tool was fashioned to support the English reading skills, and it led to significant improvements in children's letter-sound knowledge, a decisive variable and evidence in the development of initial reading process (Patel et al., 2018).

\section{Methodology}

The study applied a quantitative and descriptive research method. The subjects of the study comprised of learners from four faculties at Universiti Teknologi Mara (UiTM), Shah Alam, Malaysia. A total of 92 learners from four classes made up the treatment group; whereas, 93 students from another four classes comprised the control group. For the investigation of content elements adapted in the Multimedia Interactive Package (MIP), only the treatment group's responses (92 respondents) were analyzed and discussed in this paper. A set of questionnaires was developed and adapted using the Instructional Materials Motivation Survey (IMMS), and following feedback from content experts. For validity and reliability purposes, the survey was pilot tested before it was administered. Each content element item was tested for its internal consistency and reliability analysis (12 items; Cronbach's Alpha $=.81$ ).

\section{Results}

In gathering the treatment group's responses on the 'Content Elements', the following eleven (11) items were asked; and, Table 1 shows the responses towards the survey items. 
Table 1: Content Elements Required for the Design and Development of the MIP

\begin{tabular}{llllll}
\hline \multicolumn{1}{c}{ Item } & & SD & D & A & SA \\
\hline $\begin{array}{l}\text { 1. The learning outcomes stated in } \\
\text { the main menu inform me of the } \\
\text { skills to be learned }\end{array}$ & & & & $36(40 \%)$ & $55(60 \%)$ \\
\hline $\begin{array}{l}\text { 2. The MIP provides all necessary } \\
\text { lessons on Higher Order Thinking } \\
\text { skills (HOTs) }\end{array}$ & Exp. & 0 & 0 & $41(45 \%)$ & $50(55 \%)$ \\
\hline $\begin{array}{l}\text { 3. The short notes presented in the } \\
\text { MIP allow me to understand }\end{array}$ & Exp. ${ }^{*}$ & 0 & 0 & $44(48 \%)$ & $48(52 \%)$ \\
specific lessons more easily. & & & & & \\
\hline $\begin{array}{l}\text { 4. It is easy to look for specific lessons } \\
\text { in the MIP because they are }\end{array}$ & Exp. & 0 & 0 & $46(50 \%)$ & $46(50 \%)$ \\
presented using: & & & & & \\
$\begin{array}{l}\text { a) clear titles, bold, italics and colored } \\
\text { fonts }\end{array}$ & & & & & \\
$\begin{array}{l}\text { b) illustrations, graphs, pictures and } \\
\text { other visuals }\end{array}$ & Exp. & 0 & 0 & $38(43 \%)$ & $\begin{array}{l}51 \\
(57 \%)\end{array}$ \\
\hline
\end{tabular}

5. The MIP uses illustrations, graphs

Exp. $0 \quad 1(1 \%) \quad 63(68 \%) \quad 28(30 \%)$ and other visuals that help me to understand:

a) foreign and international contents of the reading passages (i.e. World Population, Women, Work and Career)

b) local flavored contents of the reading passages (i.e. Malaysian

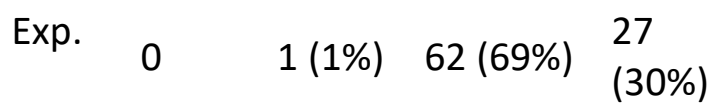
Heritage, Beggars in Malaysia)

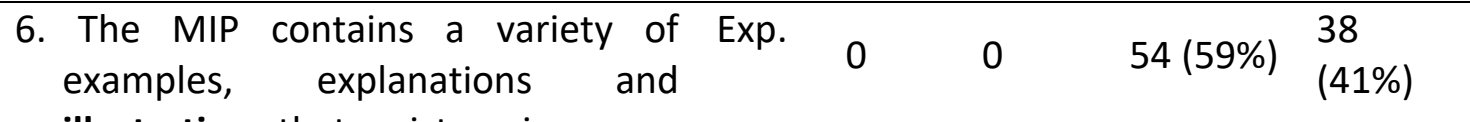
illustrations that assist me in:

a) analyzing author's argument

b) synthesizing author's argument $\begin{array}{llll}\text { Exp. } & 0 & 0 & 59(65 \%) \\ & \begin{array}{l}32 \\ (35 \%)\end{array}\end{array}$

c) evaluating author's argument

Exp. $0 \quad 1(1 \%) \quad 56(62 \%)$

7. The contents of the reading passages used in the MIP are relevant because I can relate to Exp.

39 my experience.

*Some respondents did not answer the item(s).

\section{Discussion and Conclusion}

The study examined the content elements needed to effectively design and develop a computer-mediated learning tutorial (MIP) that facilitate critical thinking skills in ESL reading. 
The findings from the content elements section of the survey reveal that 91 (99\%) learners responded either 'Agree' or 'Strongly Agree' that 'learning outcomes helped them to understand the learning contents to be learned'. Learning outcomes are important as guide for learners in their learning activities to ensure their learning success (Weir, 2005; Rendle \& Beumont, 2009). Similar studies have concurred that when learners are fully aware of their learning outcomes, they would be more prepared towards their lessons and would participate with positive interest (motivation) towards their learning experiences. For instance, Frey \& Sutton (2010) claimed that identifying and setting goals and objectives before any learning activity are crucial in ensuring the success of learning. In addition, stating the learning outcomes will also give educators the opportunity to measure learners' performances. This step is important as learners need to be aware of what they will be learning. By informing them the goals and objectives at the beginning of a lesson, learners will be aware of the type of contents and medium used and whether the materials are compatible to what they are studying (Traore \& Kyei-Blankson, 2011; Ponto, 2020).

In addition, findings also reveal that 92 (100\%) respondents reported either 'Agree' or 'Strongly Agree' that 'the contents provided in the MIP were well presented'. This is attributed to several factors such as the chunking of learning contents into smaller units of instruction, short notes with tips and feedback, elaborate examples and graphical illustrations. The researcher believes that providing necessary contents for any learning process is significant to ensure learning success. As such, arranging the contents in small chunks or digestible paragraphs can further help learners to learn, understand and remember the contents better. Apart from chunking, short notes with tips, reinforcement and immediate feedback would also contribute to the understanding and the memorization of the learning materials. It was reported that an improvement of students' achievement in reading comprehension when texts are arranged hierarchically from sentences to paragraphs (Yusuf, 2017; Wu \& Peng, 2017). Thus, comprehending complex contents can also be facilitated by presenting contents through the use of various text effects and graphical illustrations.

Furthermore, 90 (97\%) out of 91 respondents also indicated that 'their learning of reading in HOTs was facilitated with the use of both international and local-flavored reading materials'. In the MIP, the reading passages used were carefully selected from both international and local contents because incorporating local materials in reading passages can facilitate L2 learners to easily gauge contents that they are familiar with. Learners can easily relate to the learning materials if they are able to connect learning to their existing surroundings. According to Nuttall (2007), when readers attend to passages that are related to their experiences, the process of understanding the content becomes easier since they share familiar content. For instance, the use of local flavored contents of the reading passages Malaysian Heritage, Juvenile Delinquency and Beggars in Malaysia, can help learners relate to what is discussed in the passages to what is happening in their environment. This notion is parallel to what Weir (2005) and Kusumawardani (2018) have emphasized, that is, reading passages should match the purpose for reading in the real life. Although local contents or target-language situations may be more favorable, it is undeniable that the use of international contents is also important especially at the tertiary level where the use of international contents is prevalent in many disciplines such as the sciences and humanities. In facilitating learners' understanding of Higher Order Thinking skills involving analysis, synthesis and evaluation, this study incorporated in the MIP a variety of examples, 
explanations and illustrations that help to explain the author's arguments. When asked to respond to the statement above, the respondents reported either 'Agree' or 'Strongly Agree' (99-100\%) that 'the use of examples, explanations and illustrations assisted them in analyzing, synthesizing and evaluating author's arguments'. These findings imply that learners' comprehension can be facilitated by using graphical illustrations when learning complex stimuli, concepts, definitions and abstract ideas. Hence, this study proposes that the use of MIP, which is rich in visual-aided presentations using examples, mind-maps, diagrams and so forth, has great potential in ensuring learners' ability to acquire the needed skills in reading and critical thinking. Richards and Dolati (2012) stated that technology-aided media can help to translate complex verbal processes into much easier form of visual and verbal messages to be easily understood by learners. Interactive graphics (Neo, Neo \& Yap, 2008), texts, animation and sound (Ma \& Shi, 2014) used in the presentation of lessons also help learners to have a better understanding on the subjects learned. In addition, Clark \& Mayer (2011), in their study, claimed that colorful graphics, attractive fonts and audio help boost the ESL learners' cognitive skills.

The final item with regard to content elements is the relevancy of the contents of the reading passages in the MIP/Textbook to the learners' experience. Most learners (93\%) responded either 'Agree' or 'Strongly Agree' that 'the contents used in the MIP were relevant to their personal experience'. Learners' motivation (Keller, 2008) is another important factor that must be taken into consideration when selecting learning materials. Learners' attention, their sense of material relevancy, their confidence in understanding the learning materials and their satisfaction can contribute towards knowledge and skills attainment. With customized learning contents that take into consideration the learners' background and their surroundings, the researcher feels that learners' motivation towards learning can be kept at its highest. Further discussion on motivation will be dealt with when discussing the third research question in this chapter.

With the aim to gauge the efficacious of content elements to promote L2 learners' critical thinking skills by means of a deployed Multimedia Interactive Package (MIP), it can be ascertained that the MIP intervention improves L2 learners' learning success in acquiring knowledge and skills of critical thinking in ESL reading. Therefore, it is recommended that important interactive multimedia elements such as (1) learning outcomes, (2) relevant contents, (3) drills and exercises, (4) reinforcement and (5) feedback should be included in the e-learning activities. It can be further deduced that technology tools alone will make little difference if the learners could not make the connection with the learning contents and outcomes. As technology persist to permeate educational sector, this study points to two critical needs: learners need to feel the relevance of learning the materials and they need to relate to the materials within their existing surroundings. Hence, selection of appropriate contents is vital. Presenting the contents in smaller units of instruction, organizing short notes with tips and feedback, elaborating contents with visual illustrations and so forth can all ensure successful learning experiences that will yield positive performance. It is, therefore, crucial that careful and systematic instructional strategy be planned, designed and created, with appropriate content elements, prior to the development of any instructional tool. 


\section{References}

Abdul, H. A. (2016). Kemahiran berfikir aras tinggi dari aspek kurikulum, pedagogi dan pentaksiran [Higher-order thinking skills: The aspects of the curriculum, pedagogy, and assessment]. In S. Johari, I. Nor Hasniza, H. A. Abdul \& B. Yusof (Eds.) Kemahiran berfikir aras tinggi dalam pengajaran dan pembelajaran, (pp. 127-149). Johor, Skudai: Fakulti Pendidikan Universiti Teknologi Malaysia.

Alemi, M., \& Lari, Z. (2012). SMS vocabulary learning: a tool to promote reading comprehension in L2. International Journal of Linguistics, 4(4), 275. Retrieved from Questia.

Auphan, P., Ecalle, J., \& Magnan, A. (2019). Computer-based assessment of reading ability and subtypes of readers with reading comprehension difficulties: a study in French children from G2 to G9. European Journal of Psychology of Education, 34(3), 641-663.

Bataineh, A. M. (2014). The effect of electronic dictionaries and hypermedia annotations on English Major students' reading compression and vocabulary learning. International Journal of Linguistics.

Berk, R. A. (2009). Multimedia teaching with video clips: TV, movies, YouTube, and MTVU in the college classroom. International Journal of Technology in Teaching and Learning, $5(1), 1-21$.

Clark, R. C., \& Mayer, R. E. (2011). E-learning and the science of instruction: Proven guidelines for consumers and designers of multimedia learning. San Francisco, CA: Pfeiffer.

Despirt, D. (2009). Making connections while reading: Text to text, text to self \& text to world connections. Retrieved February 3, 2011, from http://www.suite101.com/ content/making-connections-and-reading-a129868

Frey, B. A., \& Sutton, J. M. (2010). Model for developing multimedia learning projects. Journal of Online Learning and Teaching, 6(2).

Ibrahim, N. N., Ayub, A. F. M., Yunus, A. S. M., Mahmud, R., \& Bakar, K. A. (2019). Effects of higher-order thinking module approach on pupils' performance at primary rural school. Malaysian Journal of Mathematical Sciences, 13(2), 211-229.

Jarvis, P. (2004). Adult education and lifelong learning: theory and practice. New York: Routledge Falmer

Keller, J. (2008). ARCS model of motivational design. Learning-Theories. Retrieved 24 February 2016 from: http://www.learningtheories.com/kellers-arcs-model-of-motivationaldesign. html

Khalifa, H. (2010). Construct validation of the reading module of an EAP proficiency test battery. Cambridge ESOL, 8-14.

Khodaparast, F., \& Ghafournia, N. (2015). The effect of asynchronous/synchronous approaches on English vocabulary achievement: A study of Iranian EFL learners. English Language Teaching, 8(4).

Krishnan, K. S., Al_Lafi, Q. A., \& Pathan, Z. H. (2013). Motivational factors that impact English Language learning in an Arab Model School, Jordan: an empirical investigation. Journal of Emerging Trends in Educational Research and Policy Studies, 4(6), 867. Retrieved from Questia.

Kusumawardani, R., Santosa, R., \& Roschsantiningsih, D. (2018). Explore the use of authentic materials to teach reading for junior high school. International Journal of Multicultural and Multireligious Understanding, 5(4), 298-307.

Ma, L., \& Shi, Z. (2014). Factors interfering students' learning effect in multimedia-based ESL classes in China. Journal of Arts and Humanities (JAH), 3(9). 
Mahmud, M. M. (2018). Technology and language-what works and what does not: A metaanalysis of blended learning research. The Journal of AsiaTEFL, 15(2), 365-382.

Mahmud, M. M., Yaacob, Y., Ramachandiran, C. R., Ching, W. S., \& Ismail, O. (2019). Theories into Practices: Bloom's Taxonomy, Comprehensive Learning Theories (CLT) and EAssessments. ICEAP 2019, 2(2), 22-27.

Moody, A. K. (2010). Using electronic books in the classroom to enhance emergent literacy skills in young children. Journal of Literacy and Technology. 11 (4), pp. 22-52

Nuttall, C. (2007). Teaching reading skills in a foreign language. (3 ${ }^{\text {rd }}$ ed.). (2005). Oxford: MacMillan.

Patel, P., Torppa, M., Aro, M., Richardson, U., \& Lyytinen, H. (2018). GraphoLearn India: The effectiveness of a computer-assisted reading intervention in supporting struggling readers of english. Frontiers in psychology, 9, 1045.

Park, C. N., \& Son, J. (2009). Implementing computer-assisted language learning in the EFL classroom: teachers' perceptions and perspectives. International Journal of Pedagogies and Learning, 5(2), 80. Retrieved from Questia.

Pearman, C. J. (2008). Independent reading of CD-ROM storybooks: measuring comprehension with oral retellings. The Reading Teacher, 61(8), 594-602.

Pinandito, A., Wulandari, C. P., Prasetya, D. D., Hirashima, T., Hayashi, Y., \& Az-Zahra, H. M. (2020). Students' acceptance towards kit-build concept map authoring tool in supporting learning of english reading comprehension. In Proceedings of the 5th International Conference on Sustainable Information Engineering and Technology ( $\mathrm{pp}$. 158-164).

Ponto, H. (2020). The Evaluation of Affective Domain Learning Outcome in Students' Basic Learning of Electrical Circuit in Vocational Education School. Journal of Computational and Theoretical Nanoscience, 17(2), 1222-1226.

Rendle, G., \& Beaumont, S. (2009). The importance of outcomes. Weekly, 254. Retrieved from http://www.alban.org/conversation.aspx?id=7956.

Richards, C., \& Dolati, I. (2012). The perception of English language teachers in the use of visual learning aids. Journal of Applied Sciences Research, 8(5), 2581-2595.

Shao, J. (2012). A study of multimedia application-based vocabulary acquisition. English Language Teaching, 5(10), 202. Retrieved from Questia.

Tomlinson, B. (2011). Materials development in language teaching. United Kingdom: Cambridge University Press.

Traore, M., \& Kyei-Blankson, L. (2011). Using literature and multiple technologies in ESL instruction. Journal of Language Teaching \& Research, 2(3), 561-568

Weir, C. J. (2005). Language testing and validation: An evidence-based approach. London: Palgrave Macmillan.

Weir, C. J., Yang, H., \& Yan, J. (2000). An empirical investigation of the componentiality of L2 reading in English. UK: University of Cambridge Local Examination Syndicate.

Weir, C., Hawkey, R., Green, A., Unaldi, A., \& Devi, S. (2005). The relationship between the academic reading construct as measured by IELTS and the reading experiences of students in their first year of study at a British university. IELTS, 9.

Wu, J. Y., \& Peng, Y. C. (2017). The modality effect on reading literacy: Perspectives from students' online reading habits, cognitive and metacognitive strategies, and web navigation skills across regions. Interactive Learning Environments, 25(7), 859-876. 
Yusuf, Q., Yusuf, Y., Yusuf, B., \& Nadya, A. (2017). Skimming and scanning techniques to assist EFL students in understanding English reading texts. Indonesian Research Journal in Education |IRJE|, 1(1), 43-57.

Zagliverinos, P. (2008). Let's update our teaching approach. ISSUES, 21. 